\title{
Development of Tibraca obscurata and Tibraca limbativentris (Hemiptera: Pentatomidae) in rice in southwestern Colombia ${ }^{1,2}$
}

\author{
Alberto Pantoja ${ }^{3}$, Mónica Triana ${ }^{4}$, Harold Bastidas ${ }^{4}$, \\ César García ${ }^{4}$ and Myriam C. Duque
}

J. Agric. Univ. P.R. 89(3-4):221-228 (2005)

\begin{abstract}
The development of Tibraca obscurata Bergroth and T. limbativentris Stal was studied in rice in southwestern Colombia. Tibraca limbativentris required more time to complete development than $T$. obscurata. Females of T. limbativentris required more time to complete development than males, but development of $T$. obscurata was similar between sexes. Tibraca limbativentris females live significantly longer than males. Tibraca limbativentris oviposited over 200 eggs in an 86-day oviposition period. The time from egg deposition to eclosion (egg incubation period) was the same (6.5 d) in the two sexes.
\end{abstract}

Key words: rice, biology, development, Tibraca obscurata, Tibraca limbativentris

\section{RESUMEN}

Desarrollo de Tibraca obscurata y Tibraca limbativentris (Hemiptera: Pentatomidae) en arroz en el suroeste de Colombia

Se estudió el desarrollo de Tibraca obscurata Bergroth y T. limbativentris Stal en arroz en el suroeste de Colombia. Tibraca limbativentris requirió mayor tiempo para completar su desarrollo que $T$. obscurata. Las hembras de T. limbativentris requirieron más tiempo para completar su desarrollo que los machos, pero el desarrollo de $T$. obscurata fue similar en los dos sexos. Las hembras de T. limbativentris son más longevas que los machos. Tibraca limbativentris depositó aproximadamente 200 huevos en un periodo de 86 días. El tiempo de incubación de los huevos fue igual para los dos sexos $(6.5 \mathrm{~d})$.

Palabras clave: arroz, biología, desarrollo, Tibraca obscurata, Tibraca limbativentris

${ }^{1}$ Manuscript submitted to Editorial Board 15 February 2005.

${ }^{2}$ The authors recognize the comments on an earlier version of this manuscript by Drs. Raúl Macchiavelli, James Beaver, Bryan Brunner, and Angel L. González from the College of Agricultural Sciences, University of Puerto Rico, Mayagüez Campus, and Dennis Fielding, USDA, ARS Fairbanks, AK.

3USDA-ARS, SARU, P.O. Box 757200, Fairbanks, AK 99775, Formerly Rice Entomologist at Centro Internacional de Agricultura Tropical (CIAT), Cali, Colombia.

${ }^{4}$ Rice Program, Centro Internacional de Agricultura Tropical, Cali, Colombia.

${ }^{5}$ Biometrics Unit, Centro Internacional de Agricultura Tropical, Cali, Colombia. 


\section{INTRODUCTION}

Fourteen species of stinkbugs (Pentatomidae) have been identified in rice in Latin America (Pantoja et al., 1995; Pantoja, 1997; Panizzi, 1997). The genus Tibraca represents the largest pentatomid in rice in this region. Two species, T. limbativentris Stal and T. obscurata Bergroth, have been reported from commercial rice fields in Latin America (Pantoja et al., 1995). The geographic distribution and the economic importance of the two species are poorly understood. However, T. obscurata is considered an economic pest in Ecuador and Venezuela, whereas T. limbativentris is an important pest in Brazil, Peru, Ecuador, the Dominican Republic, and Venezuela (Prando et al., 1993; Ferreira et al., 1997; Pantoja, 1997; González, 1998; Vivas and Clavijo, 2000). Both species usually attack upland rice, but have been recovered from irrigated rice in several countries (Prando et al., 1993; Pantoja et al., 1995; Usta et al., 1995; Pantoja, 1997; Trujillo, 1991). Tibraca limbativentris is emerging as an important rice pest in several areas of Colombia (FEDEARROZ, 1993, 1995; Pérez, 1997; Usta et al., 1995) and Venezuela (Aponte et al., 1992; Vivas and Clavijo, 2000), but limited data are available on its biology, population dynamics, and development in rice in tropical America. Prando et al. (1993) studied the life cycle of $T$. limbativentris in Brazil. However, the climate conditions and photoperiod in southern Brazil are very different from conditions in tropical areas of Colombia, Venezuela and the Caribbean, where the pest has gained economic importance. Pérez (1997) reported on T. limbativentris development in Colombia; however, these studies did not state the temperature, rearing conditions or oviposition period used in the trial, which included a total of 30 insects of both sexes. Data on the number of instars and time to complete development are important for the construction of life tables for these pests in tropical rice areas of the Americas. Information on the time to complete development and the number of instars will help in the evaluation of damage. Information on factors affecting development of stinkbug populations under field conditions is of primary importance in the development of integrated pest management (IPM) strategies. In this work, we report on T. obscurata and T. limbativentris nymphal development, oviposition, and adult longevity in rice plants of southwestern Colombia.

\section{MATERIALS AND METHODS}

Adult T. limbativentris and T. obscurata were collected in February 1991 with a standard insect net from commercial rice fields in Valle del Cauca, Colombia. Insects were confined in aluminum screen cages ( 1.5 $\times 1.5 \times 1 \mathrm{~m}$ ) provided with 90 - to 120 -d-old rice plants in $50-\times 50-\mathrm{cm}$ 
trays and were allowed to oviposit. Egg masses were removed from caged plants and allowed to hatch in petri dishes $(100 \times 15 \mathrm{~mm})$ lined with moistened filter paper. Upon eclosion, nymphs were placed individually on petri dishes provided with moistened filter paper and the basal section of a rice stem $(7$ to $8 \mathrm{~cm}$ ) with roots. Roots were washed and covered with cotton and aluminum foil to preserve humidity. Rice stems were replaced every four days. Rearing was conducted under controlled conditions at a temperature of $26^{\circ} \mathrm{C} \pm 6^{\circ}, 40 \% \mathrm{RH} \pm 10 \%, 12$ : $12 \mathrm{~h}$ dark/light conditions (CIAT, 1991). A total of $250 \mathrm{~T}$. limbativentris and $125 \mathrm{~T}$. obscurata were studied in separate trials of 50 (T. limbativentris) or 25 (T. obscurata) insects arranged in a completely randomized design. Each insect represented a replicate. Dishes were inspected daily for evidence of exuvia, which was used as an indicator of molting. The number of instars, the time in each nymphal stage, and the time from egg to adult was calculated. The sex of the adults was determined. Only data from insects that completed development to adults were used for statistical analysis. To measure reproductive parameters, we confined one virgin female and a male in a petri dish (one couple per dish) as described above. Insects were inspected every $24 \mathrm{~h}$ to detect mating and oviposition. Egg masses were removed from the dish and the eggs counted. Preoviposition days were calculated from the time of the first mating to deposition of the first egg mass. The premating period represents the time between the emergence of the adult and the first mating. The eggs were counted until the female died.

Because of unequal variances, data were analyzed by using PROC TTEST with the Satterthwaite approximation for degrees of freedom (SAS, 1999; Satterthwaite, 1946; UCLA, 2005). Degrees of freedom (DF) and significance levels $(\mathrm{P}>\mathrm{t})$ of the pooled or Satterthwaite method are provided in tables.

\section{RESULTS AND DISCUSSION}

Tibraca limbatriventis development time was significantly longer $(\mathrm{P}<0.01)$ than that of $T$. obscurata, requiring on average 10 and 25 additional days to complete nymphal and total development, respectively (Table 1). Significant differences $(P<0.01)$ in developmental time were detected between species for all stages of development except for the egg incubation period, in which the two species completed egg development in nearly equal time. Except for the first instar, T. limbativentris required a significantly longer time than $T$. obscurata to complete each developmental stage. On average, first instars of $T$. obscurata required a half day longer than $T$. limbativentris to complete that stage of development. Both species required more time to complete the fifth instar 
TABLE 1.-Developmental parameters for Tibraca limbativentris (TL) and T. obscurata (TO) in rice, Palmira, Colombia, 1991-92.

\begin{tabular}{|c|c|c|c|c|c|c|c|c|c|}
\hline & \multicolumn{9}{|c|}{ Days $\pm \mathrm{SE}$} \\
\hline & \multirow{2}{*}{$\begin{array}{c}\text { Egg } \\
\text { incubation }\end{array}$} & \multicolumn{5}{|c|}{ Instar } & \multirow{2}{*}{$\begin{array}{l}\text { Egg to } \\
\text { adult }\end{array}$} & \multirow{2}{*}{$\begin{array}{c}\text { Adult } \\
\text { longevity }\end{array}$} & \multirow{2}{*}{$\begin{array}{c}\text { Total } \\
\text { life cycle }\end{array}$} \\
\hline & & I & II & III & IV & V & & & \\
\hline$\overline{T L^{1}}$ & $6.3 \pm 0.07$ & $3.6 \pm 0.05$ & $6.8 \pm 0.08$ & $6.2 \pm 0.09$ & $7.3 \pm 0.13$ & $16.0 \pm 0.37$ & $46.2 \pm 0.46$ & $36.8 \pm 0.93$ & $82.7 \pm 0.88$ \\
\hline TO & $6.2 \pm 0.07$ & $4.1 \pm 0.08$ & $5.9 \pm 0.13$ & $5.6 \pm 0.15$ & $5.7 \pm 0.16$ & $8.7 \pm 0.15$ & $36.2 \pm 0.28$ & $36.3 \pm 0.28$ & $57.2 \pm 0.78$ \\
\hline $\mathrm{P}>/ \mathrm{T} /$ & 0.2786 & 0.0001 & 0.0001 & 0.0005 & 0.0001 & 0.0001 & 0.0001 & 0.0001 & 0.0001 \\
\hline $\mathrm{DF}^{2}$ & $237^{*}$ & $317 * * *$ & $317^{* *}$ & $317^{* * *}$ & $208^{*}$ & $290^{*}$ & $317^{*}$ & $298^{*}$ & $275^{*}$ \\
\hline
\end{tabular}

${ }^{2} \mathrm{~F}$ for variance; $*$ = Satterthwite, unequal variance; $* *$ = Pooled, equal variance. $\mathrm{n}=108$ for females and 125 for males. 
than the other instars. The time to complete fifth instar development for T. limbativentris was twice that for T. obscurata. The developmental time for T. limbativentris observed in our trial was longer than that reported in Brazil (Ferreira et al., 1997; Prando et al., 1993); however, our trial was under $26^{\circ} \mathrm{C}, 12: 12$ dark: light conditions, whereas the report from Brazil was with 14:10 h dark: light conditions and $25^{\circ} \mathrm{C}$. Temperature and photoperiod differences between the two trials are possible explanations for the developmental difference between reports from our trials and those from Ferreira et al. (1997) and Prando et al. (1993). The longer days in Brazil (14 h) as compared to $12 \mathrm{~h}$ of daylight in our trials might have provided longer periods of feeding time in the southern latitudes, thus allowing for a shorter life cycle. The developmental time (egg to adult) in our study is three days longer than that in reports by Pérez (1997) and FEDEARROZ (1993), who reported an average of $43.8 \mathrm{~d}$ for T. limbativentris development. Neither Pérez (1997) nor FEDEARROZ (1993), stated the temperature and rearing conditions used in the trial that included only 30 insects.

Developmental parameters for T. limbativentris, segregated by sex, are presented in Table 2. Significant $(\mathrm{P}<0.001)$ differences in developmental parameters were recorded for fifth instar and time from egg to adult, but both sexes completed first to fourth instar and egg development in approximately equal time. The total life cycle was significantly longer $(\mathrm{P}>0.0210)$ for females than for males. Prando et al. (1993) reported greater longevity for males than for females, but the temperature and photoperiod conditions are not comparable to those of our experiment. On the other hand, and similar to our study, Pérez (1997) reported a longer development time for T. limbativentris females than for males. For both sexes, instar one presented the shortest developmental stage, whereas the longest developmental time was recorded for instar five. Females required a significantly longer time (four days longer) than males to complete development.

Tibraca limbativentris initiated mating $11.1 \pm 0.8 \mathrm{~d}$ after reaching the adult stage. Females deposited their first eggs $6.4 \pm 0.62 \mathrm{~d}$ after mating. An average of $222.3 \pm 16.6$ eggs per female was recorded during the $86.2 \mathrm{~d}$ of the ovipositon period. Prando et al. (1993) and Pérez (1997) reported 20.6 and 14.9 eggs per T. limbativentris female, respectively, but did not state the ovipositon period. To our knowledge the present study represents the first report on the complete life cycle of the female $T$. limbativentris.

Table 3 presents developmental parameters for T. obscurata. Contrary to the case of $T$. limbativentris, no significant difference in developmental parameters was observed between sexes. To our knowledge, this research represents the first report on $T$. obscurata 
TABLE 2.-Developmental parameters for Tibraca limbativentris in rice, Palmira, Colombia, 1991-92.

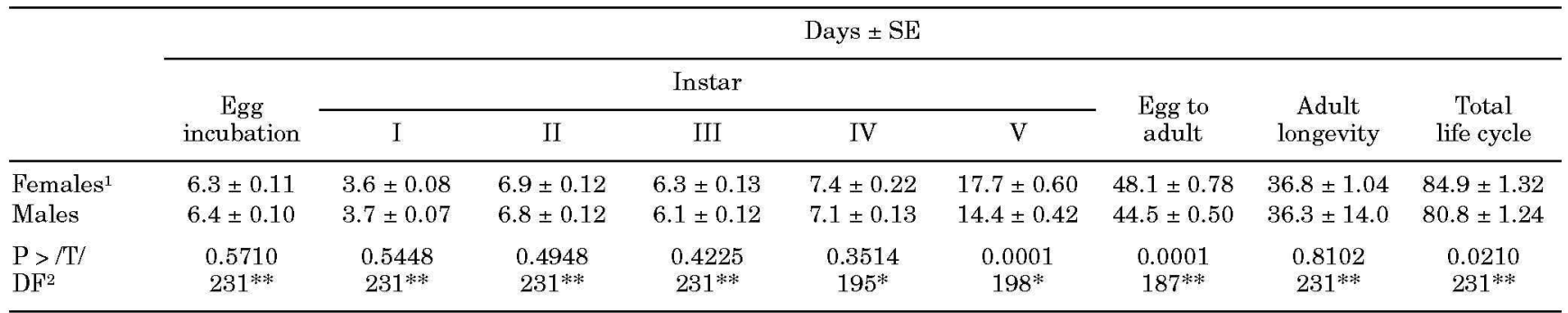

${ }^{\mathrm{n}} \mathrm{n}=108$ for females and 125 for males.

${ }^{2}$ DF for variance; * $=$ Sattertwhite, unequal variance; ** = Pooled, equal variance.

TABLE 3.-Developmental parameters for Tibraca obscurata in rice, Palmira, Colombia, 1992-93.

\begin{tabular}{|c|c|c|c|c|c|c|c|c|c|}
\hline & \multicolumn{9}{|c|}{ Days $\pm \mathrm{SE}$} \\
\hline & \multirow{2}{*}{$\begin{array}{c}\text { Egg } \\
\text { incubation }\end{array}$} & \multicolumn{5}{|c|}{ Instar } & \multirow{2}{*}{$\begin{array}{l}\text { Egg to } \\
\text { adult }\end{array}$} & \multirow{2}{*}{$\begin{array}{c}\text { Adult } \\
\text { longevity }\end{array}$} & \multirow{2}{*}{$\begin{array}{c}\text { Total } \\
\text { life cycle }\end{array}$} \\
\hline & & $\mathrm{I}$ & II & III & IV & $\mathrm{V}$ & & & \\
\hline Females $^{1}$ & $6.1 \pm 0.13$ & $4.0 \pm 0.11$ & $6.0 \pm 0.21$ & $5.7 \pm 0.25$ & $5.7 \pm 0.28$ & $8.6 \pm 0.24$ & $36.0 \pm 0.47$ & $21.1 \pm 1.60$ & $57.1 \pm 1.24$ \\
\hline Males & $6.3 \pm 0.10$ & $4.1 \pm 0.11$ & $5.8 \pm 0.17$ & $5.5 \pm 0.18$ & $5.4 \pm 0.19$ & $8.8 \pm 0.18$ & $36.3 \pm 0.36$ & $19.0 \pm 0.95$ & $57.2 \pm 1.02$ \\
\hline $\mathrm{P}>/ \mathrm{T} /$ & 0.2321 & 0.7562 & 0.6313 & 0.6053 & 0.6953 & 0.5828 & 0.6733 & 0.8978 & 0.9736 \\
\hline $\mathrm{DF}^{2}$ & 84 & 84 & 84 & 84 & 84 & 84 & 84 & 84 & 84 \\
\hline
\end{tabular}

$1_{\mathrm{n}}=35$ for females and 51 for males.

2DF for pooled variance. 
development in rice. Additional research is needed to study T. obscurata oviposition behavior on rice plants under laboratory conditions.

Both species presented a slightly higher percentage of males than females, with values of 59 and $54 \%$ for T. obscurata and T. limbativentris, respectively. Mortality was higher for T. obscurata (31\%) than for T. limbativentris (7\%). Although both species reproduced well under greenhouse conditions, $T$. obscurata did not reproduce under petri dish conditions as described in this study and was more susceptible to disturbance than $T$. limbativentris, which remained hiding in the plant tissue most of the time.

The information on the number of instars, difference in growth between sexes, and time to complete development for T. limbativentris and T. obscurata will help in the evaluation of their damage to rice and in constructing their life tables. The data presented here will be of importance in the development of IPM strategies for these two pentatomids in rice. Future work should contemplate sampling, damage functions, and establishment of threshold levels.

\section{LITERATURE CITED}

Aponte, O., L. E. Escalona, L. E. Vivas, L. M. Ramírez and F. P. Freitez, 1992. Manejo Integrado de Artrópodos Plaga en el Cultivo de Arroz en Venezuela. CIAT, Cali, Colombia.

CIAT (Centro Internacional de Agricultura Tropical), 1991. Rice Program 1986-1989 Report-CIAT working document $92.404 \mathrm{pp}$.

FEDEARRROZ (Federación Nacional de Arroceros), 1993. Estudios biológicos y fluctuación poblacional de Tibraca limbativentris (Stal). Correo FEDEARRROZ, Notitécnicas 4(37):4-5.

FEDEARROZ (Federación Nacional de Arroceros), 1995. Nivel de daño económico y hospederos alternos de Tibraca limbativentris (Stal) en arroz. pp. 106-111. In Informe Anual FEDEARROZ 1995. Santa Fe de Bogotá, Colombia.

Ferreira, E., F. J. P. Zimermann, A. Baeta dos Santos and B. Pereira das Neves, 1997. O percevejo-do-colmo na cultura do arroz. EMBRAPA-CNPAF, Goiania, Goias, Brazil, Documento \#75.

González, M., 1998. La tibraca, nuevo reto para los arroceros. Fersan Informa (República Dominicana), No. 73, año XIX, junio 1988. pp. 17-19.

Panizzi, A. R., 1997. Wild hosts of pentatomids: ecological significance and role in their pest status on crops. Ann. Rev. Entomol. 42: 99-122.

Pantoja, A., E. Daza, C. García, O. I. Mejía and D. Rider, 1995. Relative abundance of stink bugs (Hemiptera: Pentatomidae) in southwestern Colombia rice fields. J. Entomol. Sci. 30: 463-467.

Pantoja, A., 1997. Artrópodos relacionados al arroz en América Latina. pp. 59-98. In MIP en Arroz. A. Pantoja, A Fischer, F. Correa, L. R. Sanint y A. Ramírez. CIAT Publication 292. CIAT, Cali, Colombia.

Pérez, C. R., 1997. Aspectos bioecológicos de chinches. Arroz (Colombia) 46(411):20-21.

Prando, F. H., H. Kalvelange and R. A. Ferreira, 1993. Ciclo de vida de Tibraca limbativentris, 1860 (Hemiptera: Pentatomidae) em condicoes de laboratorio. Revista Brasileira Entomologia 37(2): 335-339.

SAS Institute, 1999. The SAS system version 8 for windows. SAS Institute, Cary, NC. 
Satterthwaite, F. W., 1946. An approximate distribution of estimates of variance components. Biometrics Bulletin 2:110-114.

Trujillo, M. R., 1991. Chinche grande del Arroz: Biología y Control. Instituto Nacional de Tecnología Agropecuaria, Estación Experimental Agropecuaria, Corrientes, Argentina, Mayo 1991. 16 pp.

UCLA, 2004. Academic Technologies Services. http://www.ats.ucla.edu/stat/sas/output/ ttest.htm

Usta, A., C. R. Pérez and V. Lobaton, 1995. Nivel de daño económico y hospederos alternos de Tibraca limbatriventis (Stal) 1860 en Arroz. In Proceedings. XXII Congreso de la Sociedad Colombiana de Entomología. Santa Fe de Bogotá, Colombia, July 26$28,1995$.

Vivas, L. E. and S. Clavijo, 2000. Fluctuación poblacional de Tagosodes orizicolus (Muir) 1926 (Homoptera: Delphacidae) en el sistema de riego Río Guarico, Calabozo, Estado Guarico, Venezuela. Boletín Entomológico Venezolano 15(2):217-227. 